\title{
Naphthalene Removal with Layered Double Hydroxides
}

\begin{abstract}
Naphthalene is a hazardous pollutant. It has a negative impact on human health and environment. Its manufacturing process is accompanied by gaseous naphthalene emissions into the air of the premises and then into the atmosphere, thus polluting the environment. There is currently no existing method to remove naphthalene from the gas phase which is capable of meeting the required environmental standards. The goal of this research was to investigate the mechanism of naphthalene removal from the gas phase by the sorption method using $\mathrm{Mg} /(\mathrm{Al}+\mathrm{Mg})$ layered double hydroxides (LDHs) and to develop naphthalene removal technology to meet the required environmental standards. The methods for obtaining selective sorbents of naphthalene and its derivatives have been investigated. The technology of naphthalene removal from gas phase using $\mathrm{Mg} /(\mathrm{Al}+\mathrm{Mg}) \mathrm{LDHs}$ has been developed. The technological parameters of reactors have been calculated. The final concentration of naphthalene of $12 \mathrm{mg} / \mathrm{m}^{3}$ was obtained which appeared to be lower than the maximum allowed concentration. The efficiency of naphthalene sorption with LDHs was found to be over $95 \%$.
\end{abstract}

Keywords: naphthalene, sorption, layered double hydroxides, pollution

Received: 9 September 2018; accepted: 19 February 2020

(C) 2020 Authors. This is an open access publication, which can be used, distributed and reproduced in any medium according to the Creative Commons CC-BY 4.0 License.

1 Pryazovskyi State Technical University, Metallurgical Faculty, Department of Chemical Technology and Engineering, Mariupol, Ukraine, email: butenkoeo@rambler.ru

ORCID ID: https://orcid.org/0000-0002-6296-2075

2 The John Paul II Catholic University of Lublin, Faculty of Engineering and Technical Sciences in Stalowa Wola, Department of Environmental Engineering, Poland, email: danelena.leo@gmail.com (corresponding author)

ORCID ID: https://orcid.org/0000-0001-9948-2182

3 Miami University, Havighurst Center, Oxford, Ohio, USA, email: kapustinlesha@gmail.com ORCID ID: https://orcid.org/0000-0003-1253-0351

4 AGH University of Science and Technology, Faculty of Mining Surveying and Environmental Engineering, Department of Environmental Management and Protection, Krakow, Poland, email: elenad@agh.edu.pl

ORCID ID: https://orcid.org/0000-0002-4665-0928 


\section{Introduction}

Naphthalene is one of products of the "INCORE" Company. Its manufacturing process is accompanied with gaseous naphthalene emissions into the air of the premises and then into the atmosphere, thus polluting the environment. In addition, naphthalene is one of the most important coal-tar resin refinement products. It is a valuable raw material for the chemical industry. Naphthalene maximal extraction from coal-tar resin and its rational use is of paramount importance [1].

The main source of naphthalene is a naphthalene fraction, derived via resin fractioning which contains up to $85 \%$ naphthalene. There is about $92-93 \%$ of naphthalene total content in the resin. The naphthalene fraction contains up to $6 \%$ of methyl-naphthalene, $3.8 \%$ of thionaphthene, $2.3 \%$ of phenols, $0.4 \%$ of unsaturated compounds and up to $0.3 \%$ of indole [2].

Naphthalene is one of the 16 polycyclic aromatic hydrocarbons included in the Environmental Protection Agency (EPA) list [3]. The National Institute for Occupational Safety and Health (NIOSH USA) has set a recommended naphthalene exposure limit at $10 \mathrm{ppm}$ (or $50 \mathrm{mg} / \mathrm{m}^{3}$ ) over an eight-hour time-weighted average, as well as a short-term exposure limit at $15 \mathrm{ppm}$ (or $\left.75 \mathrm{mg} / \mathrm{m}^{3}\right)$ [4].

In recent years, naphthalene has attracted increased attention due to its high toxicity, mutagenicity, and carcinogenicity [5]. Naphthalene is a poisonous substance, which is why mothballs and other products containing naphthalene have been banned within the EU since 2008 [6]. The lethal dose of naphthalene for adults is $10 \mathrm{~g}$, and $2 \mathrm{~g}$ for children. Poisoning can happen via the inhalation of naphthalene vapor or dust, as well as due to penetration through the skin or into the stomach. Naphthalene dust in the air is explosive at $1.7-8.2 \%$.

Currently, various methods of entrapping and neutralizing naphthalene compounds from the air are used. Gas purification methods are used in industry, such as absorption, adsorption, catalytic, thermal and others [7]. Design methods are based on mass and heat transfer regularities. It is worth noting that the adsorption processes are of great interest, since adsorption is an effective method for the removal of naphthalene due to its capability to efficiently adsorb different types of contaminants and design simplicity [8]. Moreover, adsorption is the most universal way to purify emissions from gaseous contaminants. It is possible to remove any contaminant from emissions in a wide range of concentrations via adsorption. However, it is more convenient to implement a preliminary treatment (condensation, absorption) for highly concentrated contaminants (supposedly, with concentrations exceeding $10^{-3} \mathrm{~kg} / \mathrm{m}^{3}$ ) to reduce their concentrations. Adsorption also finds applications in the case of the selective removal of specific gases from a certain mixture. Finally, adsorption is the best method to reach trace concentrations.

The outgoing flowing gas is composed of air, water and naphthalene, according to the required installation design for naphthalene removal from ventilation emissions at the department of pressed naphthalene processing. The emissions also 
contain $\alpha$-methylnaphthalene according to the data obtained with chromatographic analysis, which is listed below.

The most important parameter for naphthalene removal from the gas phase is the dependence of the partial pressure with temperature, which is evaluated here and shown in Figure 1 [9].

a)

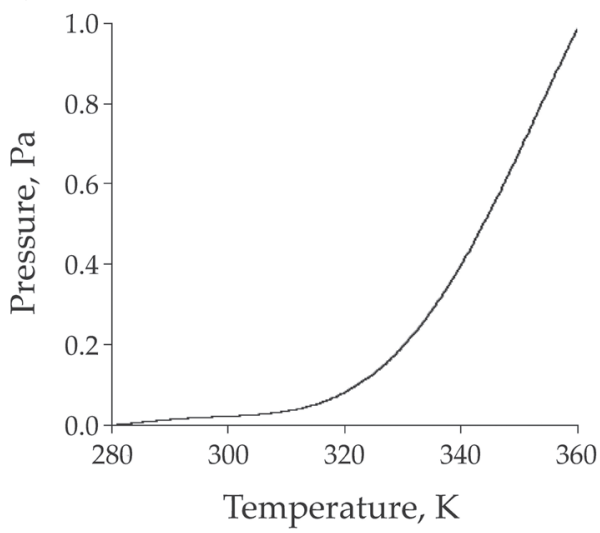

b)

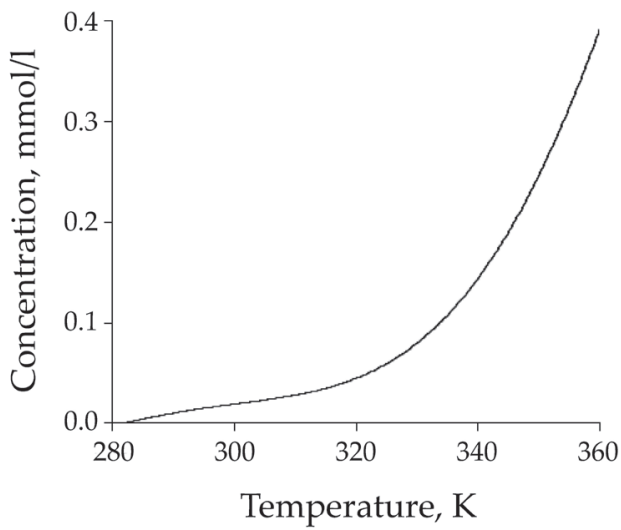

Fig. 1. Temperature dependence of naphthalene saturated vapors partial pressure (a) and concentration (b)

Source: [9]

Naphthalene concentration of $20 \mathrm{mg} / \mathrm{m}^{3}$ corresponds to $0.156 \mu \mathrm{mol} / \mathrm{L}$. It corresponds to pressure of $0.00088 \mathrm{kPa}$ as well as temperature of $264.75 \mathrm{~K}$ or $-8^{\circ} \mathrm{C}$.

A well-known method for naphthalene absorption is its entrapment by organic solvents, mostly with absorption oil [10]. An effective final concentration was found to be $400-800 \mathrm{mg} / \mathrm{m}^{3}$. The following naphthalene removal methods have also been reported: adsorption on activated carbon, polymeric carriers, metals, zeolites etc. The gas cleaning method by washing with water and introducing any naphthalene solvent (e.g., light resin) into the flushing water is known as well.

\section{Problem Statement and Research Purpose}

This work is based on research for designing installations for naphthalene removal from ventilation emissions at an enterprise belonging to the "INCORE" Company. The aforementioned company is a subsidiary of the "Metinvest Holding". The main requirement for the installation was to reach a final concentration of naphthalene of below $20 \mathrm{mg} / \mathrm{m}^{3}$, in order to meet Ukrainian environmental standards (Tab. 1). 
Table 1. Main specifications for naphthalene removal technology

\begin{tabular}{|l|c|}
\hline Initial naphthalene concentration & $1000 \mathrm{mg} / \mathrm{m}^{3}$ \\
\hline Temperature of emission & $50^{\circ} \mathrm{C}$ \\
\hline Volume flow rate & $300 \mathrm{~m}^{3} / \mathrm{h}$ \\
\hline Relative humidity & $50 \%$ \\
\hline
\end{tabular}

Nowadays there are a variety of naphthalene removal methods and its derivatives from the gas phase, including physical and chemical ones, rectification, absorption, adsorption and others [11-14]. As yet, however, there is no existing method of naphthalene removal from gas which meets the required environmental standard of $20 \mathrm{mg} / \mathrm{m}^{3}$. Reaching such parameters requires the development of a special technological process of naphthalene removal from the gaseous phase. The purpose of this work is to develop such processes.

The research purpose was to investigate the mechanism of naphthalene removal from the gaseous phase by the sorption method using $\mathrm{Mg} /(\mathrm{Al}+\mathrm{Mg})$ layered double hydroxides (LDHs) and to develop a naphthalene removal technology to reach the required ecological parameters.

\section{Methodology}

The methods that could be laid into developed technology foundations may include: absorption method; method of catalytic destruction; method of thermal neutralization; condensation method; adsorption method.

Absorption naphthalene removal is possible even with water. Aromatic hydrocarbon vapors are absorbed by the "air-water" system. The wet adsorption process through the formation of fog with subsequent dewing is used. Water droplet formation from fog particles of 14 to 200 microns in size is required for efficient absorption and vapor naphthalene removal with subsequent condensation. At particle sizes smaller than 50 microns, naphthalene vapor absorption is higher than from their "gas-liquid" phase equilibrium. In other words, surface adsorption takes place. Surface active substance introduction has a positive effect on naphthalene vapor absorption by water droplets.

Experiments were conducted for naphthalene and $\beta$-naphthole sorption on $\mathrm{Mg} /(\mathrm{Al}+\mathrm{Mg}) \mathrm{LDHs}$ with different molar content of $\mathrm{Mg}$ and $\mathrm{Al}, \mathrm{mol} / \mathrm{mol}: 0.52,0.72$, $0.81,0.86$.

$\mathrm{Mg} /(\mathrm{Mg}+\mathrm{Al}) \mathrm{LDH}$ can be obtained from chemical production wastes containing $\mathrm{Mg}$ and $\mathrm{Al}$ salts. LDHs are produced as a commercial product by the SASOL (Germany) and Kyowa (Japan) companies. In addition, LDHs can be synthesized in laboratory conditions.

In this work, LDHs samples synthesized under laboratory conditions were used. Syntheses were performed by co-precipitation. 
A solution of metal salts $\mathrm{Mg}\left(\mathrm{NO}_{3}\right)_{2}$ and $\mathrm{Al}\left(\mathrm{NO}_{3}\right)_{3}$ with concentrations close to $100 \mathrm{~g} / \mathrm{L}$, taken in stoichiometric ratios, was poured into a solution containing about two times excess alkali and carbonates under stirring (final $\mathrm{pH}$ value $=8-10$ ). The precipitate crystallizes under heating for at least 18 hours. Solutions of $\mathrm{NaOH}$ and $\mathrm{Na}_{2} \mathrm{CO}_{3}$ were used as a precipitant. The precipitation time took place within 24 hours, and the crystallization time was 96 hours at $80^{\circ} \mathrm{C}$. The obtained samples were washed to reach neutralization and dried at $120^{\circ} \mathrm{C}$.

\section{Results and Discussion}

We chose to compare naphthalene with $\beta$-naphthole because $\beta$-naphthole and naphthalene sorptions occur via different mechanisms. After completion of the sorption process, the specific surface was determined and interplane distances were measured. Changes in internal space dimensions were identified with the help of phase $X$-ray analysis [15]. The results of the experiments are summarized in Figure 2. Three powder X-ray diffraction patterns (Fig. 2) are very similar, showing very little structural alternation. It can be seen in the detached insertion that intensities drop, and the 11.8-degree peak shifted towards two smaller theta angles. This shift to the left shows an increase in inter-plane distance; it verifies the diffusion of the organic molecules into the lattice, which is also confirmed by the fact that there are also similar shifts at angles of 43,61 and 62 degrees. A change in the structure is observed. There are some peak shifts and increases in intensity appear. The position and intensity of other peaks remain unchanged.

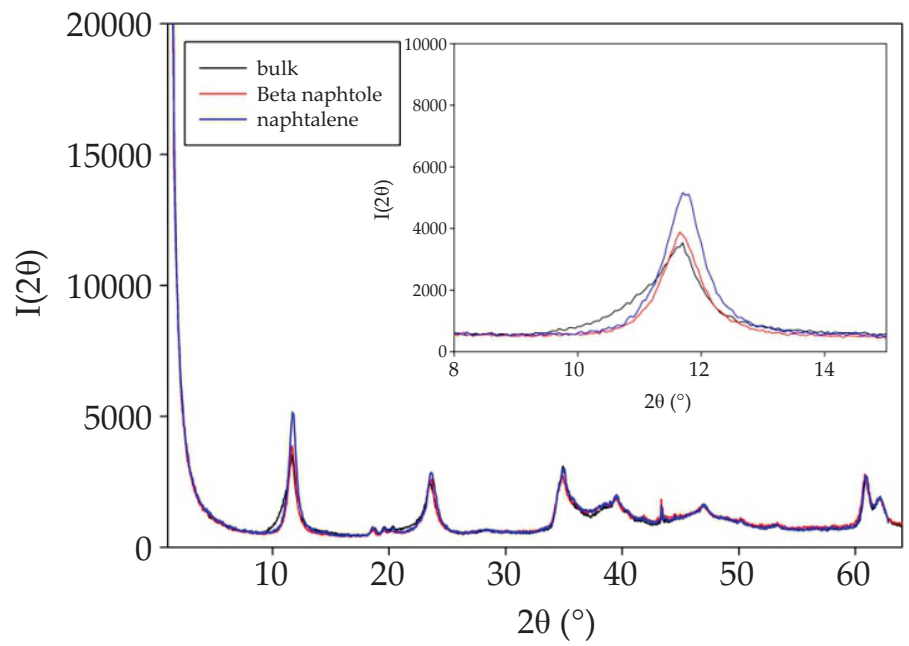

Fig. 2. Powder X-ray diffraction pattern of $\mathrm{LDH} \mathrm{Mg} /(\mathrm{Mg}+\mathrm{Al})=0.72 \mathrm{~mol} / \mathrm{mol}$ (initial, with naphthalene - in blue and with $\beta$-naphthole - in red) 
It can be seen on Figure 2 that the highest deviations are observed for the $\beta$-naphthole sorption. The possible reason is due to the fact that the adsorbed naphthalene aromatic rings are arranged in parallel to the inorganic layers, irrespective of the concentration of active sites. Interactions of $\pi$-electrons of aromatic rings with the matrix layers lead to changes in interplane distance.

The specific surface of the sorbents with adsorbed organic compounds was determined by the Brunauer-Emmett-Teller (BET) method. The results are summarized in Table 2.

Table 2. Specific surface value for layered double hydroxide specimens

\begin{tabular}{|c|c|c|c||}
\hline \hline $\mathrm{Mg} /(\mathrm{Al}+\mathrm{Mg})[\mathrm{mol} / \mathrm{mol}]$ & Initial $\left[\mathrm{m}^{2} / \mathrm{g}\right]$ & $\beta$-naphthole $\left[\mathrm{m}^{2} / \mathrm{g}\right]$ & Naphthalene $\left[\mathrm{m}^{2} / \mathrm{g}\right]$ \\
\hline \hline 0.52 & 162.4 & 155.7 & 156.0 \\
\hline 0.72 & 14.4 & 14.4 & 14.4 \\
\hline 0.81 & 9.2 & 12.0 & 19.59 \\
\hline 0.86 & 22.0 & 28.0 & 34.7 \\
\hline
\end{tabular}

It can be seen from the data represented in Table 2 that the low values of the relation $\mathrm{Mg} /(\mathrm{Al}+\mathrm{Mg})$ sorption of naphthalene and $\beta$-naphthole has practically no influence upon specific values, while at high values of $\mathrm{Mg} /(\mathrm{Al}+\mathrm{Mg})$, the changes are much greater.

Naphthalene sorption is a physical sorption process. $\beta$-naphthole is a relatively strong acid and the sorption process goes on much faster than for alcohols. Adsorbed naphthalene aromatic rings are arranged in parallel to inorganic layers, irrespective of the concentration of active sites. The inter-plane distance is about $7 \AA$. This value is comparable to the "thickness" of the aromatic ring, which is equal to $3.5 \AA$, while the diameter of a benzene molecule is $7.1 \AA$. And for $\beta$-naphthole, a plane-parallel arrangement is observed only at the initial ionic exchange stage (Fig. 3) [16].
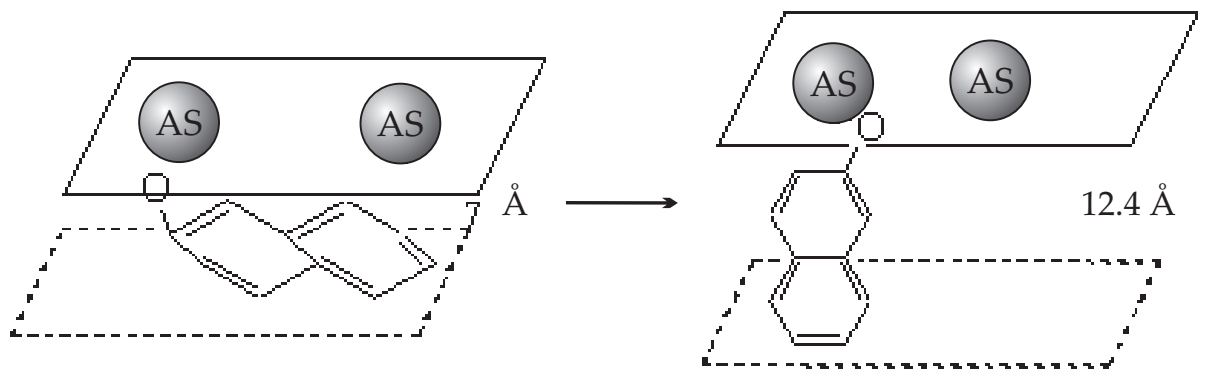

Fig. 3. Naphthole molecules alternation arrangement in an ionic exchange process Source: [17] 
An efficient area for $\beta$-naphthole is $9.89 \AA^{2}$. Later equilibrium is set, accompanied by an increase in inter-plane distance and growth in the number of active sites available for the following $\beta$-naphthole molecules. This process is accompanied by an enlargement of the specific surface of layered double hydroxides.

The dependence of a specific surface changes after naphthalene and $\beta$-naphthole sorption, depending upon the layered double hydroxides content as shown in Figure 4.

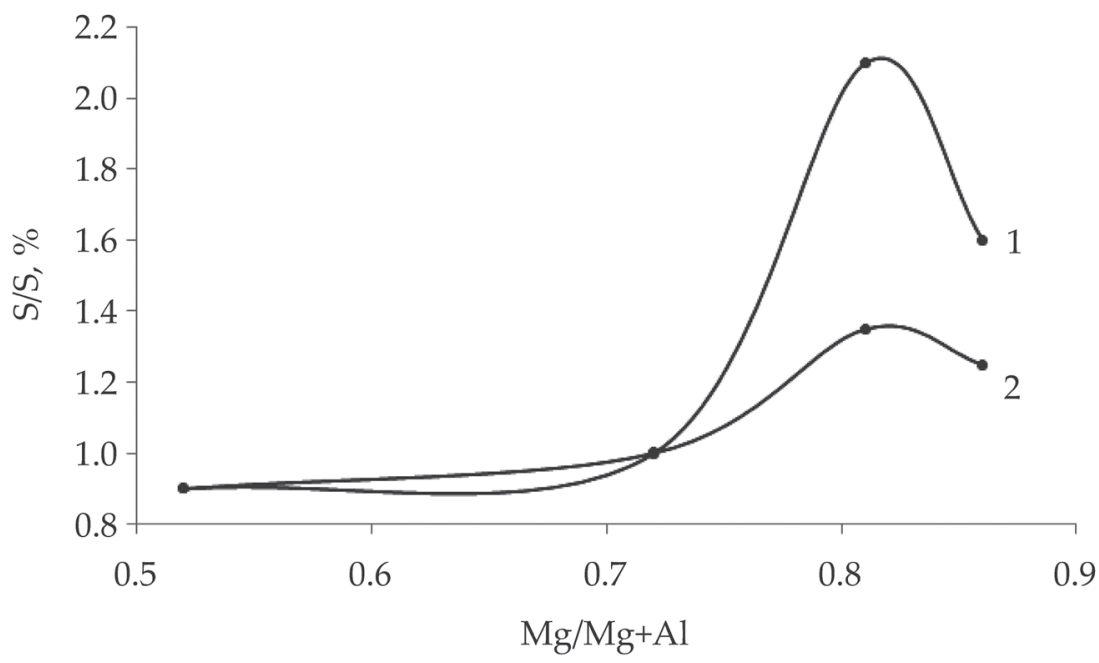

Fig. 4. Relative change of the specific surface, depending upon the composition of double hydroxides:

1 - with naphthalene, 2 - with $\beta$-naphthole

Source: [17]

It can be seen that with an increase in the degree of isomorphous substitution, organic compounds sorption leads to big changes in the specific surface [17].

\section{Proposed Technology for Naphthalene Removal}

The following scheme was chosen to simulate an industrial naphthalene sorption process (Fig. 5). Naphthalene was placed on the vessel bottom 2 and air was blown over the naphthalene. Then it passed through a tube and entered a reactor filled with sorbent 3 . The air was preliminarily dehumidified by passing it through a trap equipped with a drier 1 . The inlet Á and outlet B temperatures were controlled, with the required time for reaching a stationary mode determined as being about half an hour. The gas flow passed through a cryoscopic trap 4. Naphthalene was dissolved in diethyl ether and then underwent chromatography. 


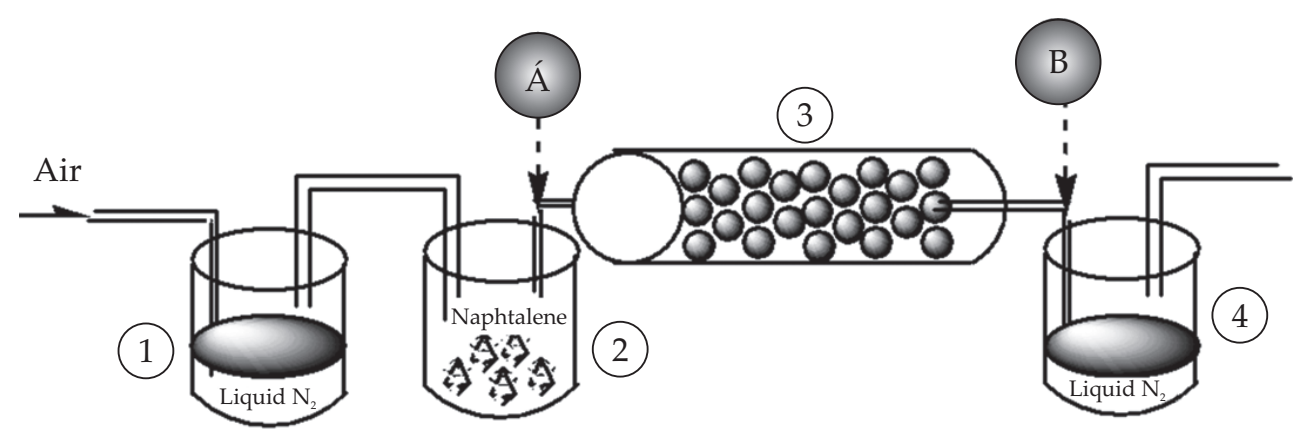

Fig. 5. Laboratory installation for the removal of naphthalene from the gaseous phase Source: [18]

The gas flow rate was $0.05 \mathrm{~m} / \mathrm{s}$, initial naphthalene concentration $230 \mathrm{mg} / \mathrm{m}^{3}$, the final $12 \mathrm{mg} / \mathrm{m}^{3}$.

During the investigations for the neutralization of coke-oven production emissions, it was discovered that the air and vapor naphthalene mixture, upon contact with the adsorbent, leads to the intense desublimation which occurs on its surface. Naphthalene solid particles skipped through the adsorbent layer, increasing its concentration in the air after the adsorber.

When the air and naphthalene vapor mixture touches a fresh adsorbent surface, two processes occur simultaneously - adsorption and desublimation. As these processes are of a competing character, it may be supposed that desublimation will proceed more intensely on the adsorbent which has already been saturated with naphthalene.

The desublimation process was investigated on LDHs. The naphthalene mixture was delivered from the metering device to the filter for airborne particles removal and then it was passed on to the sorbent. The diameter of the device is $40 \mathrm{~mm}$, the air flow rate is $0.03 \mathrm{~m} / \mathrm{s}$, the height of sorbent layer is $45 \mathrm{~cm}$. Samples were taken before and after the sorption process. Naphthalene concentrations were determined by means of photocolorimetry with alloxantin. The initial naphthalene concentration was about $200-300 \mathrm{mg} / \mathrm{m}^{3}$.

An efficient way of improving the dynamic sorbent capacity method is the additional introduction of substances which suppress desublimation. The research results showed that the 1:10 introduction of benzene vapors in relation to naphthalene increased the exchange capacity by $25-30 \%$ and similar $\alpha$-methylnaphthalene introduction increased the exchange capacity by 15-20\%. Desublimation suppression can be explained by the deceleration of the chain reaction of the sublimate formation.

At super-low naphthalene concentrations, desorption and sublimation were not observed.

Figure 6 shows the principal diagram of naphthalene removal from the gas flow by LDHs. 


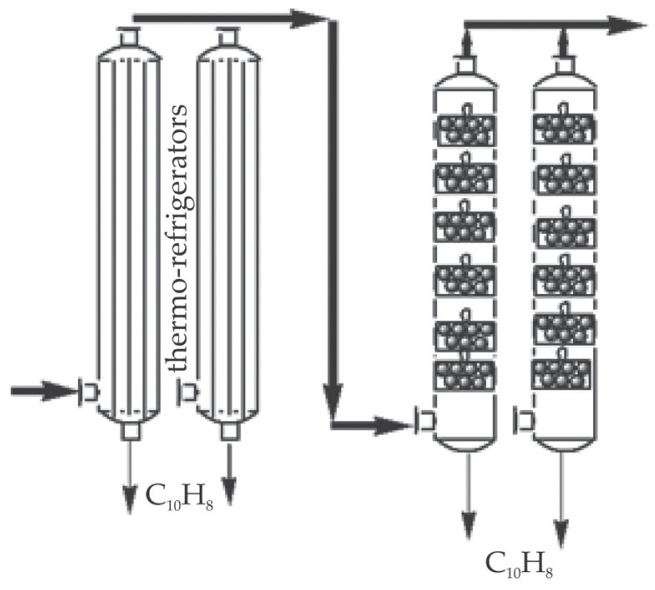

Fig. 6. Adsorption columns, alternatively operating for naphthalene adsorption, equipped with LDHs

Source: [18]

The results obtained were the basis for sorption apparatus design (Fig. 6) for bringing naphthalene emissions to maximum permissible concentrations requirements.

\section{Conclusions}

1. The process of naphthalene removal from the gas phase in the presence of $\mathrm{Mg} /(\mathrm{Al}+\mathrm{Mg}) \mathrm{LDHs}$ as sorbents was investigated. It was found, on the basis of results achieved using the BET method, that low values of $\mathrm{Mg} /(\mathrm{Al}+\mathrm{Mg})$ relation (0.52) sorption of naphthalene and $\beta$-naphthole has a significantly smaller influence upon specific values in comparison with high values of $\mathrm{Mg} /(\mathrm{Al}+\mathrm{Mg})$ relation (0.86).

2. In this paper, technology for the removal of naphthalene from the gas phase is proposed. The schematic diagram and basic parameters are given.

3. The desublimation process on LDHs was also investigated. An efficient way of increasing the dynamic sorbent capacity method is by means of the introduction of additional substances (e.g. benzene vapors, $\alpha$-methylnaphthalene) which suppress desublimation.

4. Purification to the maximum allowable concentration and below can be carried out using $\mathrm{Mg} /(\mathrm{Mg}+\mathrm{Al})$ layered double hydroxides with interplanar distances of a size corresponding to the size of naphthalene molecules. A final concentration of naphthalene of $12 \mathrm{mg} / \mathrm{m}^{3}$ was obtained.

5. The efficiency of naphthalene sorption removal by means of layered double hydroxides can reach above $95 \%$. 


\section{References}

[1] Franck H.-G., Stadelhofer J.W.: Naphthalene - production and uses. [in:] Industrial Aromatic Chemistry: Raw Materials. Processes. Products, Springer-Verlag Berlin Heidelberg, 1988, pp. 298-333.

[2] Fin A., Petkova I., Doval D.A.: Naphthalene- and perylenediimides with hydroquinones, catechols, boronicesters and imines in the core. Organic and Biomolecular Chemistry, vol. 9, no. 24, 2011, pp. 8246-8252. https://doi.org/10.1039/ c1ob05702b.

[3] Liu P., Wu Z., Ge X., Yang X.: Hydrothermal synthesis and microwave-assisted activation of starch-derived carbons as an effective adsorbent for naphthalene removal. RSC Advances, vol. 9, 2019, pp. 11696-11706. https://doi.org/10.1039/ C9RA01386E.

[4] National Institute for Occupational Safety and Health. Education and Information Division. https://www.cdc.gov/niosh/npg/npgd0439.html [access: 11.04.2016].

[5] Sun Z., Wu Z., Liu D., He X.: Microwave-assisted modification of activated carbon with cationic surfactants for enhancement of naphthalene adsorption. Korean Journal of Chemical Engineering, vol. 35, 2018, pp. 557-566. https://doi. org/10.1007/s11814-017-0290-z.

[6] Gray K.: Council warned against use of poisonous moth balls. Your Local Guardian, 2013. http://www.yourlocalguardian.co.uk/news/10813745.Council_warns_ against_use_of_poisonous_mothballs [access: 17.11.2013].

[7] Nazarov V.G.: Removal of naphthalene and tar from coke-oven gas in primary cooling and condensation. Coke and Chemistry, vol. 59, no. 6, 2016, pp. 221-234. https://doi.org/10.3103/S1068364X16060053.

[8] Gan S., Lau E.V., Ng H.K: Remediation of soils contaminated with polycyclic aromatic hydrocarbons (PAHs). Journal of Hazardous Materials, vol. 172 (2-3), 2009, pp. 532-549. https://doi.org/10.1016/j.jhazmat.2009.07.118.

[9] Fowler L., Trump W.N., Vogler C.E.: Vapor pressure of naphthalene - new measurements between $40^{\circ} \mathrm{C}$ and $180^{\circ} \mathrm{C}$. Journal of Chemical \& Engineering Data, vol. 13, no. 2, 1968, pp. 209-210.

[10] Reichardt P.E., White D.L.: Estimation of Naphthalene in Absorbing Oil. Industrial and Engineering Chemistry, Analytical Edition, vol. 18, no. 5, 1946, pp. 286-288. https://doi.org/10.1021/i560153a004.

[11] Gregorio F.D., Parrillo F., Salzano E., Cammarota F., Arena U.: Removal of naphthalene by activated carbons from hot gas. Chemical Engineering Journal, vol. 291, 2016, pp. 244-253. https://doi.org/10.1016/j.cej.2016.01.081.

[12] Gonzalez-Azpiroz M.D., Gutierrez Blanco C., Casal Banciella M.D.: The use of solvents for purifying industrial naphthalene from coal tar distilled oils. Fuel Processing Technology, vol. 89, no. 2, 2008, pp. 111-117. https://doi.org/ 10.1016/j.fuproc.2007.06.001. 
[13] Huang S.-D., Valsaraj K.T., Wilson D.J.: Removal of Refractory Organics by Aeration. V. Solvent Sublation of Naphthalene and Phenanthrene. Separation Science and Technology, vol. 18, no. 10, 1983, pp. 941-968. https://doi. org/10.1080/01496398308060318.

[14] Sharma A., Lee B.-K.: Adsorptive/photo-catalytic process for naphthalene removal from aqueous media using in-situ nickel doped titanium nanocomposite. Journal of Environmental Management, vol. 155, 2015, pp. 114-122. https://doi. org/10.1016/j.jenvman.2015.03.008.

[15] Butenko E.O., Kapustin A.E., Kravchenko V.S.: Changes in the structure of $\mathrm{Mg}_{x} \mathrm{Al}_{y}(\mathrm{OH})_{z}$ layered double hydroxides during the adsorption of organic compounds. Journal of Structural Chemistry, vol. 52, no. 2, 2011, pp. 436-438. https://doi.org/10.1134/S0022476611020284

[16] Butenko E., Kapustin A.: Changes in the structure of layered double hydroxides during the adsorption of organic compounds. [in:] Materiály X Mezinárodní vĕdecko-praktická konference "Vĕda a technologie: krok do budoucnosti - 2014", Díl 31: Výstavba a architektura. Chemie a chemická technologie, Education and Science, Praha 2014, pp. 58-62.

[17] Butenko E., Malyshev A., Kapustin A.: Influence of Hydrocarbon Radicals on the Structure of Layered Double Hydroxides. American Journal of Materials Science and Engineering, vol. 2, no. 1, 2014, pp. 1-6. https://doi.org/10.12691/ ajmse-2-1-1.

[18] Butenko E.: Selective Removal of Naphthalene by Means of Anionic Clays Different Composition. Medcave Journal of Environmental Science \& Technology, vol. 1, no. 1, 2019, pp. 1-4.

\section{Usuwanie naftalenu}

\section{za pomocą warstwowych podwójnych wodorotlenków}

Streszczenie: Naftalen należy do niebezpiecznych substancji, które mają negatywny wpływ na ludzkie zdrowie i środowisko. Procesowi jego produkcji towarzyszy emisja naftalenu gazowego do atmosfery, co przyczynia się do zanieczyszczenia innych elementów środowiska przyrodniczego. Obecnie nie istnieje efektywny sposób usuwania naftalenu z fazy gazowej, który zapewniłby spełnienie wymaganych standardów ekologicznych. Celem niniejszych badań było zbadanie mechanizmu usuwania naftalenu z fazy gazowej metodą sorpcji z zastosowaniem warstwowych materiałów nieorganicznych i na tej podstawie opracowanie efektywnej technologii usuwania naftalenu. Obliczono parametry technologiczne reaktorów oraz opracowano technologię usuwania naftalenu i jego pochodnych z zastosowaniem selektywnych sorbentów: warstwowych podwójnych wodorotlenków na bazie $\mathrm{Mg} /(\mathrm{Al}+\mathrm{Mg})$. $\mathrm{W}$ wyniku eksperymentu realizowanego w warunkach laboratoryjnych 
z zastosowaniem opracowanej metody udało się osiągnąć stężenia naftalenu $\mathrm{w}$ fazie gazowej na poziomie $12 \mathrm{mg} / \mathrm{m}^{3}$, co nie przekracza ustalonych maksymalnych dopuszczalnych wartości. Efektywność redukcji naftalenu za pomocą warstwowych podwójnych wodorotlenków wynosi w tym przypadku ponad $95 \%$.

Słowa

kluczowe: naftalen, sorpcja, warstwowe podwójne wodorotlenki, zanieczyszczenie 